\title{
Nutritional quality of Pilosocereus gounellei using different spine removal and plant storage methods
}

\author{
[Qualidade nutritiva de Pilosocereus gounellei em relação a diferentes métodos de retirada \\ dos acúleos e ao armazenamento] \\ R.M.F. Magalhães ${ }^{1}$, M.S.S. Carneiro ${ }^{1}$, A.B. Castro $^{1}$, R.L. Edvan ${ }^{2 *}$, \\ E.S. Pereira ${ }^{1}$, S.F. Silva ${ }^{1}$, J.N.C. Torreão ${ }^{2}$ \\ ${ }^{1}$ Universidade Federal do Ceará - Fortaleza, CE \\ ${ }^{2}$ Universidade Federal do Piauí - Bom Jesus, PI
}

\begin{abstract}
This study aimed to evaluate the nutritional quality of Pilosocereus gounellei using different methods of spine removal and plant storage. A total of $600 P$. gounellei cacti were randomly selected in 10 hectares of Caatinga. The experimental design was completely randomised using a 2 x 4 factorial arrangement and three replicates. The variables evaluated were the storage conditions (under trees; and ventilated storage facilities) and four types of spine removal techniques assessed 31 days after storage (fresh plants with spines [control]; use of flamethrowers before storage; slash-and-burn ["coivara"] before storage; and use of flamethrowers after storage). The P. gounellei subjected to slash-and-burn during the cladode harvest (cutting) process deteriorated rapidly and exhibited a smooth consistency; dark colour. The burning process resulted in increased in situ degradability of dry matter compared with the control treatment. The results of treatment 4 were similar to those of the control treatment regarding the preservation of the nutritional properties of $P$. gounellei. Therefore, $P$. gounellei can be harvested and stored fresh for 31 days without losing their nutritional properties, and spines should be removed using flamethrowers after the storage period, i.e., when using the plants as livestock feed.
\end{abstract}

Keywords: caatinga, cactus, semiarid, $P$. gounellei

\section{RESUMO}

Objetivou-se com o presente trabalho avaliar a qualidade nutritiva do Pilosocereus gounellei em relação a diferentes métodos de retirada dos acúleos e ao armazenamento. Foram selecionadas ao acaso $600 \mathrm{P}$. gounelleis em 10 hectares de caatinga nativa. $O$ delineamento experimental foi inteiramente ao acaso, em esquema fatorial $(2 \times 4)$, com três repetições. Os fatores constaram dos locais de armazenamento (primeiro local: árvore. segundo local: galpão) e de quatro tipos de processamento de eliminação dos acúleos do P. gounellei (tratamento 1: in natura, com acúleo (testemunha); tratamento 2: utilização de lança-chamas por ocasião do armazenamento; tratamento 3: queima em coivara por ocasião do armazenamento; tratamento 4: lança-chamas após o armazenamento), avaliado após 31 dias do armazenamento. $O$ P. gounellei queimado em coivara por ocasião do corte (tratamento 3) degradou-se rapidamente, apresentando consistência lisa e coloração escurecida. Em relação à degradabilidade in situ da matéria seca, os tratamentos com fogo proporcionaram maiores valores que o tratamento 1. $O$ tratamento 4 foi o que apresentou resultados mais próximos ao 1 (P. gounellei in natura), conservando as propriedades nutricionais do $\mathrm{P}$. gounellei. $O \mathrm{P}$. gounellei pode ser colhido e armazenado in natura por 31 dias, sendo preservadas suas qualidades nutricionais, com retirada dos acúleos com lança-chamas após o armazenamento, no momento de fornecer aos animais.

Palavras-chave: caatinga, cactácea, semiárido, P. gounellei

Recebido em 13 de fevereiro de 2017

Aceito em 17 de maio de 2018

*Autor para correspondência (corresponding author)

E-mail: edvan@ufpi.edu.br 


\section{INTRODUCTION}

Caatinga vegetation is the main source of forage for livestock in the semi-arid region in Northeast Brazil (Santos et al., 2010), the main cultivated forages are not adapted to the environment or have low yields. This way, native cacti Pilosocereus gounellei and Cereus jamacaru stand out in relation to these introduced species and are used during prolonged periods of drought as strategic forage feed for ruminants in ruminant feed (Silva et al., 2013).

These plants are found in regions with high temperatures and are resistant to drought because they have specialised physiological mechanisms for water storage, which makes them water reserves and food that can meet the needs of livestock in the dry season. It is important to note that $P$. gounellei cacti should be used as a last resort (i.e., as a strategic forage) because of its slow growth. Silva et al. (2011) planted 10,000 $P$. gounellei cacti per hectare and obtained a mean productivity of $1120 \mathrm{~kg}$ of dry matter per hectare 6.5 years after planting. This forage resource, when combined with other food sources, results in good livestock production in these regions.

For animals that consume $P$. gounellei as food, the spines must be removed. According to Cavalcanti and Resende (2007), the spines can cause serious damage, such as perforation of the eyes, mouth, stomach, and other parts of these animals. It is common to find producers who remove the spines using slash-and-burn techniques or campfires or by directly burning the plant. However, these methods are not advisable because they can cause serious damage to the sites subjected to burning and can impair plant regrowth and decrease the feed quality. Therefore, producers have adopted novel methods of spine removal from $P$. gounellei using butane flamethrowers.

Some ranchers from Inhamuns, in Ceará, Brazil, reported that most of the used cactaceous was mandacaru, but over the years this plant became difficult to find, so $P$. gounelle $i$ is more currently used. However, this plant has a slow growth and a more expensive handling process because of their spines, as it is necessary to burn the forage material for animal feeding (Lima, 1998). P. gounellei is very important in the food chain of the semiarid biome, to providing fruit, nectar and rods which are widely used in the nutrition of ruminants, mainly sheep and goats. The sustainable use of the plant is becoming increasingly important, especially with the advance of desertification, and its rational use ensures the satiation of the appetite of the animals, without putting the species at risk of extinction.

Consequently, it was decided to test whether there was any loss in nutritional quality of $P$. gounellei, taking into consideration the storage location, removal of spines and storage time, since the location under the tree could have a larger influence on temperature and humidity. Santos et al. (1998), for instance, evaluated the performance of dairy cows fed with forage cactus stored for different periods and realized that the storage period had no effect on the palm of consumption.

For the process of collection and use in animal feed of $P$. gounellei to be less laborious, this study aimed to verify the chemical composition and in situ degrability of $P$. gounellei cacti using distinct methods of spine removal and plant storage.

\section{MATERIALS AND METHODS}

The experiment was conducted in the geographical macro-region of the Inhamuns hinterlands in Boa Vista Farm, Barra Nova district, at $\mathrm{km} 138$ of highway BR-020, in the municipality of Tauá, state of Ceará, Brazil, located at $05^{\circ} 45^{\prime} \mathrm{S}$ latitude and $40^{\circ} 08^{\prime} \mathrm{W}$ longitude, with an elevation of 500m (GPS).

According to the Köppen classification, the climate type is BSw'h, hot and semi-arid. The topography of the region is flat, slightly hilly, or hilly, with elevations varying between $400 \mathrm{~m}$ and $600 \mathrm{~m}$ and a predominance of hyper xerophilic Caatinga vegetation (Perfil..., 2011).

The experimental period ran from October 7 to November 6, 2013; there was no rainfall in this period. During the experiment, the minimum, mean, and maximum temperatures and relative humidity were recorded.

To conduct the study, an area of 10 hectares was demarcated that consisted of a biome typical of the Inhamuns hinterlands, characterised by the predominance of $P$. gounellei vegetation. Soil samples were analysed to determine its chemical characteristics (Table 1). 
Table 1. Chemical characteristics of the soil in the experimental area of Barra Nova, Tauá district, state of Ceará, Brazil

\begin{tabular}{|c|c|c|c|c|c|c|c|}
\hline Depth & $\mathrm{pH}$ & & & T & & \multicolumn{2}{|c|}{ M } \\
\hline$(\mathrm{cm})$ & $\left(\mathrm{H}_{2} \mathrm{O}\right)$ & \multicolumn{2}{|c|}{$\left(\mathrm{mg} \mathrm{dm}^{-3}\right)$} & & & ---- \% & \\
\hline $0-20$ & 6.1 & & & 7 & & 0 & \\
\hline $\mathrm{K}$ & $\mathrm{Ca}$ & $\mathrm{Mg}$ & $\mathrm{Na}$ & $\begin{array}{c}\mathrm{Al} \\
\text { Cmolc dm }\end{array}$ & $\mathrm{H}+\mathrm{Al}$ & SB & CTC \\
\hline 28 & 14.2 & 6.8 & 5.6 & 0 & 0 & 49 & 49 \\
\hline
\end{tabular}

pH in water using 1:2.5 soil to water extraction; P - K - Na using the Mehlich-1 extraction method; Ca $\mathrm{Mg}$ - $\mathrm{Al}$ extracted using $\mathrm{KCl}$ at $1 \mathrm{~mol} \mathrm{~L}^{-1}$.

The measures of depth $(\mathrm{cm}), \mathrm{pH}\left(\mathrm{H}_{2} \mathrm{O}\right), \mathrm{P}(\mathrm{mg}$ $\left.\mathrm{dm}^{-3}\right), \mathrm{V}$ and $\mathrm{M}$ were, respectively, 0-20, 8.1, 142,100 and 0 . Also, the soil was classified as Brown and Non-Calcareous according to the soil assessment-identification survey performed by the Brazilian Corporation of Agricultural Research (Sistema..., 2013). According to the guidelines of the Brazilian System of Soil Classification (Sistema..., 2009) of 2009, the soil was classified as Chromic Luvisol.

The experimental design was completely randomised using a $2 \times 4$ factorial scheme and three replicates (each repeating with 25 plants). The variables evaluated were the storage site (under trees or in ventilated storage facilities) and four types spine removal techniques assessed 31 days after storage (fresh plants containing spines [control]; spine removal with flamethrowers before storage; spine removal by slash-and-burn ["coivara"] before storage; and spine removal using flamethrowers after storage).

For evaluation of the $P$. gounellei plants were randomly selected, 75 for each treatment (each repeating with 25 plants), with a total of 600 plants evaluated in the experiment. Plants with similar height, crown diameter, stem diameter at ground level, and number of primary branches were selected. After plant selection, $40 \mathrm{~cm}$-long primary branches were removed, transported to the storage facility, and separated for application of each treatment. After each treatment for spine removal was applied, the samples were stored either under a tree or in a ventilated storage facility, on top of pallets in both cases.

Three 900g samples were collected per treatment and stored in labelled clear plastic bags, immediately placed in a cooler containing ice and stored at approximately $-5^{\circ} \mathrm{C}$. These samples were transferred to a forced ventilation oven and dried at $65^{\circ} \mathrm{C}$ for 72 hours. The final drying was carried out at $105^{\circ} \mathrm{C}$, to determine the total dry matter. The samples were ground in a mill with a 1-mm mesh sieve. The contents of total dry matter (DM - method No. 934.01), ether extract (EE - method No. 920.39), and ash (AC - method No. 942.05) were analysed according to the method described by AOAC (Official..., 1990), and crude protein (CP) using the Kjeldahl method (method No. 981.10). The neutral detergent fiber (NDF) and acid detergent fiber (ADF) content was determined as described by Van Soest et al. (1991). The organic material (OM) was determined by the difference between $\mathrm{DM}$ and $\mathrm{AC}$ values, according to Campos et al. (2004). Total carbohydrate (TC) was determined using the following formula: $\mathrm{TC}=100-(\% \mathrm{CP}+$ $\% \mathrm{EE}+\% \mathrm{AC}$ ), and the non-fibrous carbohydrate content (NFC) was determined according to the difference between TC and NDF, as described by Hall (1997).

The total dry matter degradability percentage was calculated using in situ degradation. This study followed the ethical principles of the Ethics Committee for Animal Experimentation of the Federal University of Piaui under protocol number 016/14. In the evaluation of degradability in situ three Santa Inês sheep were used, at about 12 months old and with average weight of $40 \mathrm{~kg}$, with permanent rumen cannulas. The animals used in the experiment, belong to the Small Ruminants Research Unit of the Bom Jesus Technical School, located at the Bom Jesus, Piauí.

The experimental isoproteic feeds were formulated according to NRC (Nutrient..., 2001). During the experiment the animals were subjected to an adaptation period of 15 days. During this period the animals were fed with a diet of the forage and concentrated corn meal, soybean and mineral supplement $(60: 40)$, twice a 
day (8:00 am and 6:00 pm) in sufficient amount to allow about $10 \%$ of leftovers. The samples were placed in nylon bags $(13 \mathrm{~cm} \times 5 \mathrm{~cm})$ with 50 -micron porosity. The bags were weighed dry, and $3.0 \mathrm{~g}$ of pre-dried sample was then added to each bag. The bags were then sealed with rubber bands and an iron ring, attached to a chain, and incubated in the rumen for $144 \mathrm{~h}$, the degradability assessment was made only for that time. After their removal from the rumen, the nylon bags were washed in cold water and dried at $65^{\circ} \mathrm{C}$ for 72 hours. The following parameters were calculated for each treatment (as percentages) using the incubation: in situ dry matter degradation (ISDMD), in situ ash degradation (ISACD), and in situ organic matter degradation (ISOMD).

Data analysis was performed using the general linear model (GLM) procedure of the SAS statistical package (Statistical..., 2003), and the means were compared using Tukey's test $(\mathrm{P}<$ 0.05 ) according to the following equation:

$$
\mathrm{y}_{\mathrm{ijkl}}=\mu+\mathrm{ts}_{\mathrm{i}}+\mathrm{tp}_{\mathrm{j}}+\mathrm{ts}_{\mathrm{i}^{*}} \mathrm{tp}_{\mathrm{j}}+\mathrm{e}_{\mathrm{ijkl}},
$$

Where:

$\mathrm{y}_{\mathrm{ijkl}}=$ dependent variable $(\mathrm{DM}, \mathrm{AC}, \mathrm{CP}, \mathrm{EE}$, NDF, and ADF);

$\mu=$ means of the variables;

$\mathrm{ts}_{\mathrm{i}}=$ type of storage (tree; and storage facility);

$\mathrm{tp}_{\mathrm{j}}=$ type of processing for spine removal: (fresh

plants with spines [control]; use of flamethrowers before storage; slash-and-burn before storage; and use of flamethrowers after storage);

$\mathrm{ts}_{\mathrm{i}} * \mathrm{p}_{\mathrm{j}}=$ interaction between type of storage and type of processing; and

$\mathrm{e}_{\mathrm{ijk}}=$ random error and error associated with each observation.

Also, using the same procedure (GLM, using Tukey's test), the variables (y) that were used for the degradability were: dry matter (DM), mineral matter (MM) and organic matter (OM).

\section{RESULTS AND DISCUSSION}

No significant differences were observed for $\mathrm{DM}, \mathrm{AC}, \mathrm{CP}, \mathrm{EE}, \mathrm{NDF}, \mathrm{ADF}, \mathrm{TC}$, total dry matter (TDM), NFC, and OM between storage sites (tree and storage facility). This result indicates that the storage conditions did not affect the chemical composition of the plants stored. Santos et al. (1992) evaluated the chemical composition of the cladodes of forage cacti subjected to different storage periods in a storage facility that was covered but with open sides and observed no apparent changes in the contents of DM, CP, crude fibre, and soluble carbohydrates during the storage period.

The rapid healing of the plant regions from which the cladodes were cut, which occurs after seven days, is one of the reasons for the preservation of the plant structures after cutting. During the storage period, the relative humidity varied between $26.75 \%$ and $87.80 \%$, and the temperature varied between $20.8^{\circ} \mathrm{C}$ and $33.8^{\circ} \mathrm{C}$. The variations in the environmental conditions recorded (Table 2) did not cause changes in the preservation of the cladodes under the two storage conditions after 31 days. Neves et al. (2010) found that the cactus pear (Opuntia ficusindica) could be harvested and stored for up to 16 days without changing the DM intake and milk production in cattle.

With regard to the spine removal methods, the DM content in treatment burning with flamethrowers before storage was the lowest and differed significantly from all other treatments (Table 3), most likely because these plants lost less water and more spines during the burning process. The DM content in treatment fresh plants with spines; control, was similar to that of treatments slash-and-burn before storage and burning with flamethrowers after storage.

The AC in treatment spine removal with flamethrowers before storage was the highest and differed significantly $(\mathrm{P}<0.001)$ from the other treatments, most likely because the plants in this treatment had a higher DM content as a result of the more intense burning process. The AC was similar to that reported by Barbosa (1997).

The data obtained from CP shows that treatments fresh plants containing spines [control] and spine removal using flamethrowers after storage had the highest contents. This protein loss probably happens due to the loss of water during the process of removal of spines, since the plants stay there, after being set on fire, until the fire goes out. In this case, there is no control of the extracted spines; on the other hand, when setting fire to the plants with the flamethrower, 
considering the case of treatment 4 , there is control over the spines. This is why the plant probably loses less water and presents minor levels of protein. However, it was not possible to find any references to support this finding. The $\mathrm{CP}$ values obtained were lower than those reported by Cavalcanti and Resende (2007) $(5.89 \%)$.

Table 2. Relative humidity and air temperature during the $P$. gounellei plant storage period in the Caatinga in Ceará, Brazil, measured through a single thermometer available at the weather station

\begin{tabular}{|c|c|c|c|c|c|c|}
\hline \multirow[b]{2}{*}{ Month/day } & \multicolumn{4}{|c|}{ Relative humidity (\%) } & \multicolumn{2}{|c|}{ Air temperature $\left({ }^{\circ} \mathrm{C}\right)$} \\
\hline & 9:00 am & 3:00 pm & Minimum & Maximum & Minimum & Maximum \\
\hline Oct/07 & 65.60 & 39.70 & 33.50 & 79.80 & 22.40 & 32.60 \\
\hline Oct/08 & 64.80 & 32.50 & 29.70 & 79.90 & 22.90 & 33.40 \\
\hline Oct/09 & 64.80 & 32.00 & 32.00 & 80.70 & 22.30 & 33.40 \\
\hline Oct/10 & 61.10 & 33.10 & 29.70 & 79.60 & 22.50 & 33.50 \\
\hline Oct/11 & 56.90 & 32.10 & 32.10 & 76.30 & 22.70 & 32.90 \\
\hline Oct/12 & 56.70 & 39.80 & 38.40 & 77.70 & 23.40 & 32.40 \\
\hline Oct/13 & 59.90 & 38.40 & 37.80 & 83.90 & 22.20 & 31.20 \\
\hline Oct/14 & 52.70 & 26.70 & 26.00 & 76.50 & 21.60 & 33.20 \\
\hline Oct/15 & 58.50 & 30.10 & 29.40 & 76.10 & 22.90 & 33.80 \\
\hline Oct/16 & 66.30 & 33.30 & 35.50 & 77.70 & 23.20 & 33.40 \\
\hline Oct/17 & 59.30 & 32.90 & 32.30 & 79.40 & 21.90 & 33.80 \\
\hline Oct/18 & 67.90 & 37.10 & 36.40 & 78.00 & 22.90 & 33.00 \\
\hline Oct/19 & 57.70 & 31.40 & 28.20 & 76.40 & 22.00 & 33.30 \\
\hline Oct/20 & 66.20 & 33.60 & 30.40 & 78.80 & 21.40 & 33.20 \\
\hline Oct/21 & 66.20 & 32.60 & 29.10 & 75.70 & 22.20 & 31.10 \\
\hline Oct $/ 22$ & 66.60 & 24.60 & 20.30 & 80.10 & 22.40 & 34.10 \\
\hline Oct $/ 23$ & 68.20 & 40.20 & 33.90 & 78.30 & 22.30 & 31.50 \\
\hline Oct/24 & 66.80 & 36.30 & 33.60 & 81.80 & 22.30 & 32.90 \\
\hline Oct $/ 25$ & 68.60 & 37.00 & 36.50 & 82.30 & 22.60 & 33.40 \\
\hline Oct/26 & 71.60 & 36.60 & 36.50 & 81.50 & 22.80 & 33.60 \\
\hline Oct/27 & 70.70 & 43.30 & 41.20 & 80.20 & 22.80 & 32.30 \\
\hline Oct/28 & 76.00 & 42.30 & 39.80 & 83.00 & 22.70 & 32.50 \\
\hline Oct/29 & 74.90 & 41.00 & 37.50 & 79.30 & 22.30 & 33.00 \\
\hline Oct/30 & 62.70 & 36.40 & 31.60 & 74.70 & 22.70 & 33.60 \\
\hline Oct/31 & 66.10 & 36.40 & 30.50 & 76.60 & 22.20 & 32.70 \\
\hline Nov/01 & 64.40 & 30.90 & 29.60 & 78.10 & 21.30 & 32.90 \\
\hline Nov/02 & 69.20 & 37.30 & 34.40 & 80.10 & 22.70 & 33.70 \\
\hline Nov/03 & 67.70 & 64.30 & 55.30 & 78.00 & 24.50 & 29.90 \\
\hline Nov/04 & 82.80 & 49.70 & 49.70 & 87.80 & 20.80 & 29.50 \\
\hline Nov/05 & 66.00 & 41.40 & 39.80 & 83.10 & 22.80 & 31.80 \\
\hline Nov/06 & 69.40 & 38.60 & 36.00 & 78.40 & 23.50 & 32.40 \\
\hline
\end{tabular}

Source: National Institute of Meteorology - INMET. Station: 81758 - Fortaleza, Ceará. 
Table 3. Dry matter (DM), ash content (AC), crude protein (CP), ether extract (EE), neutral detergent fibre (NDF), acid detergent fibre (ADF), total carbohydrates (TC), total dry matter (TDM), non-fibrous carbohydrates (NFC), and organic matter (OM) of $P$. gounellei subjected to distinct storage conditions and different methods of spine removal

\begin{tabular}{|c|c|c|c|c|c|c|}
\hline \multirow[t]{2}{*}{ Variables } & \multicolumn{2}{|c|}{ Storage } & \multicolumn{4}{|c|}{$\begin{array}{l}\text { Spine removal } \\
\text { method }\end{array}$} \\
\hline & Storage facility & Tree & T1 & $\mathrm{T} 2$ & T3 & T4 \\
\hline \multicolumn{7}{|c|}{ 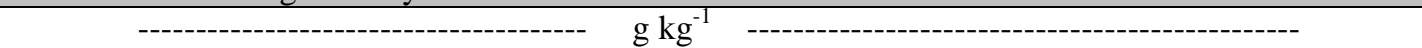 } \\
\hline DM & $919.9 \mathrm{a}$ & $919.5 \mathrm{a}$ & $920.7 \mathrm{a}$ & $922.5 \mathrm{a}$ & $915.7 b$ & 919.0ba \\
\hline \multicolumn{7}{|c|}{ 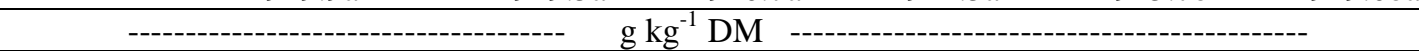 } \\
\hline $\mathrm{AC}$ & $178.7 \mathrm{a}$ & $177.4 \mathrm{a}$ & $174.8 \mathrm{~b}$ & $182.5 \mathrm{a}$ & $177.7 \mathrm{~b}$ & $177.6 \mathrm{~b}$ \\
\hline $\mathrm{CP}$ & $38.2 \mathrm{a}$ & $36.1 \mathrm{a}$ & $39.2 \mathrm{a}$ & $31.5 \mathrm{c}$ & $35.3 b$ & $39.3 a$ \\
\hline $\mathrm{EE}$ & $11.7 \mathrm{a}$ & $11.0 \mathrm{a}$ & $13.7 \mathrm{a}$ & $07.8 \mathrm{~d}$ & $10.2 \mathrm{c}$ & $12.2 \mathrm{~b}$ \\
\hline NDF & $659.6 \mathrm{a}$ & $668.6 \mathrm{a}$ & $678.1 \mathrm{a}$ & $643.2 b$ & $669.8 \mathrm{a}$ & $656.8 \mathrm{~b}$ \\
\hline $\mathrm{ADF}$ & $444.8 \mathrm{a}$ & $442.1 \mathrm{a}$ & $457.7 \mathrm{a}$ & $437.0 \mathrm{ab}$ & $434.8 b$ & $424.1 \mathrm{~b}$ \\
\hline $\mathrm{TC}$ & $771.3 \mathrm{a}$ & $775.5 \mathrm{a}$ & $772.1 \mathrm{~b}$ & $778.1 \mathrm{a}$ & $776.8 \mathrm{a}$ & $771.0 \mathrm{~b}$ \\
\hline TDM & $116.0 \mathrm{a}$ & 117.1a & $112.2 \mathrm{c}$ & $120.0 \mathrm{a}$ & $119.4 a$ & $116.6 \mathrm{~b}$ \\
\hline $\mathrm{NFC}$ & $111.6 a$ & $107.0 \mathrm{a}$ & $94.0 \mathrm{c}$ & $134.9 \mathrm{a}$ & 107.0b & $114.1 \mathrm{~b}$ \\
\hline OM & $741.2 \mathrm{a}$ & $742.1 \mathrm{a}$ & $745.8 \mathrm{a}$ & $740.0 \mathrm{~b}$ & 738.1c & $741.8 \mathrm{~b}$ \\
\hline
\end{tabular}

Means followed by the same letters in the row do not differ significantly according to Tukey's test at 5\% probability. The order of comparison was from the largest to the smallest mean.

T1: fresh P. gounellei plants containing spines (control); T2: P. gounellei plants subjected to slash-andburn before storage; T3: $P$. gounellei plants subjected to spine removal using flamethrowers before storage; and T4: $P$. gounellei plants subjected to spine removal using flamethrowers before their collection and after storage.

The CP values obtained in treatment fresh plants containing spines [control] were lower than those reported by Silva et al. (2005). The protein content is directly related to climatic factors, season, water availability, plant age, part of the plant collected, and plant handling during sample preparation. Fontes et al. (2010) evaluated different morphological parts of $P$. gounellei at two years of age to identify the parts with the highest nutritional values and observed that the younger parts had higher CP contents compared with older parts.

The EE content differed significantly among all treatments $(\mathrm{P}<0.001)$. Plants from treatment fresh plants containing spines [control] had the highest mean EE content, most likely because they were not subjected to burning; therefore, their spines, which are highly combustible, were preserved. According to Malainine et al. (2003), the surface of cactus spines has thick wax-rich cuticles that protect the plants against heat. Treatment spine removal using flamethrowers after storage (removal of P. gounellei plants spines before their collection, after the storage) had the second highest mean EE content, most likely because fewer $P$. gounellei plants underwent spine removal using flamethrowers, which made the spine removal process more energy efficient and exposed the plant to minimal heat.

Treatment spine removal with flamethrowers before storage (slash-and-burn before storage) had the lowest mean EE content. This finding was most likely due to exposure to high temperatures during burning, which volatilised the fatty acids present in the plant cuticles.

The NDF content was greater in treatments fresh plants containing spines [control] and spine removal by slash-and-burn ["coivara"]. Of note, treatment fresh plants containing spines [control] was not subjected to any spine removal process, which explains the higher NDF content. Treatment spine removal by slash-and-burn ["coivara"] had higher NDF content because the spines may not have been thoroughly burned. The difference in the NDF content between treatments spine removal with flamethrowers before storage and spine removal using flamethrowers after storage was not significant $(\mathrm{P}<0.001)$, most likely because both treatments burned the spines thoroughly. The NDF content in treatment [control] was higher than that reported by Fontes et al. (2010). In addition, 
these authors reported that the older parts of the plant exhibited higher NDF contents.

Table 3 shows that the ADF content was not significantly different between treatments [control] and spine removal with flamethrowers before storage. This result may indicate that spine burning in treatment spine removal with flamethrowers before storage was not homogeneous and that the more spines present in the plant, the greater the fibre content is.

Treatments spine removal with flamethrowers before storage and spine removal by slash-andburn ["coivara"] before storage had the highest TC contents - although the difference between the two treatments was not significant $(\mathrm{P}>0.05)$ - most likely because these treatments were subjected to high temperatures for a longer period, which resulted in decreased $\mathrm{CP}, \mathrm{EE}$, and AC contents, directly affecting the TC content (Table 3). Treatments [control] and spine removal using flamethrowers after storage had the lowest TC contents - although the difference between the two treatments was not significant most likely because these treatments did not result in many changes in the $\mathrm{CP}, \mathrm{EE}$, and $\mathrm{AC}$, as they did not use high temperatures.

Treatments spine removal with flamethrowers before storage and spine removal by slash-andburn ["coivara"] before storage had the highest TDM contents, although the difference between the two treatments was not significant. This finding was most likely because both treatments involved high temperatures for longer periods, which caused more severe dehydration. Treatment [control] had the lowest average TDM content because these plants were not subjected to any burning process; therefore, dehydration did not occur. The TDM content in treatment [control] was similar to that reported by Barbosa (1997).

Table 3 shows that treatment spine removal with flamethrowers before storage had the highest average NFC content. In addition, this value differed significantly from the other treatments, most likely because plants in treatment spine removal with flamethrowers before storage were subjected to a higher temperature for a longer period, which decreased the amount of spines and the fibre content in the plant epidermis, directly affecting the NFC content. The NFC value in treatment [control] was the lowest and was significantly different from other treatments. This result may indicate that the spines present in treatment [control] caused decreases in the NFC contents. NFCs are rapidly fermented in the rumen, improving the energy supply to the animal (Cavalcanti et al., 2008), a fact that indicates that treatments spine removal with flamethrowers before storage and spine removal using flamethrowers after storage achieved better results for the CNF content.

The OM content in treatment [control] was the highest and was significantly different from the other treatments, most likely because the fresh $P$. gounellei plants did not undergo any changes during the burning process; however, it is probable that animals would not consume plants with spines. The OM content obtained in treatment [control] was lower than that reported by Barbosa (1997), most likely because of the soil type and climatic differences.

Importantly, the plants subjected to slash-andburn during the cutting process (treatment spine removal by slash-and-burn ["coivara"] before storage) were rapidly degraded and achieved a smooth consistency and dark colour, in addition to higher contents of DM, AC, TC, NFC and smaller contents of CP, EE, and NDF. The fresh $P$. gounellei plants performed well as livestock feed after spine removal. According to Pereira Filho et al. (2013), the Caatinga's resources should be used fresh primarily for goats and sheep.

ISDMD, ISACD, and ISOMD did not differ $(\mathrm{P}<$ 0.001 ) in relation to the storage method (Table 4 ), indicating that these storage methods retained the nutritional value of the plants. 
Table 4. In situ dry matter degradability (ISDMD), in situ ash content degradability (ISACD), and in situ organic matter degradability of (ISOMD) of $P$. gounellei subjected to different storage conditions and different spine removal procedures

\begin{tabular}{|c|c|c|c|c|c|c|c|}
\hline \multirow{2}{*}{ Variables } & \multicolumn{2}{|c|}{ Storage } & \multicolumn{5}{|c|}{$\begin{array}{c}\text { Spine Removal } \\
\text { Method }\end{array}$} \\
\hline & Storage facility & Tree & & $\mathrm{T} 1$ & $\mathrm{~T} 2$ & $\mathrm{~T} 3$ & T4 \\
\hline & \multicolumn{7}{|c|}{---------------------------------------- ％ ----------------------------------------- } \\
\hline ISDMD & $96.21 \mathrm{a}$ & $95.78 \mathrm{a}$ & $94.74 b$ & $96.61 \mathrm{a}$ & $96.51 \mathrm{a}$ & & $.98 \mathrm{a}$ \\
\hline ISACD & $20.36 \mathrm{a}$ & $19.43 \mathrm{a}$ & $14.55 \mathrm{~b}$ & $20.59 \mathrm{a}$ & $21.61 \mathrm{a}$ & & $.69 \mathrm{a}$ \\
\hline ISOMD & $75.85 \mathrm{a}$ & $76.35 \mathrm{a}$ & $80.19 \mathrm{a}$ & $76.02 b$ & $74.89 \mathrm{~b}$ & & $.29 b$ \\
\hline
\end{tabular}

Means followed by the same letters in the row are not significantly different according to Tukey's test at 5\% probability. The order of comparison was from the largest to the smallest mean.

T1: fresh $P$. gounellei plants containing spines (control); T2: P. gounellei plants subjected to slash-and-burn before storage; T3: $P$. gounellei plants subjected to spine removal using flamethrowers before storage; and T4: $P$. gounellei plants subjected to spine removal using flamethrowers before sample collection.

For the different spine removal methods, ISDMD was lower in treatment [control] (control) and higher in other treatments, although this variable was not significantly different among these three treatments. This result indicates that the burning process increased the degradability of $P$. gounellei plants. Similarly, ISACD was lower in treatment [control] and higher in other treatments, indicating that the burning process was responsible for the increase in ISDAC, considering that the $\mathrm{AC}$ increased and the ISOMD decreased during spine burning. Therefore, spine burning resulted in increased degradability of $P$. gounellei plants; after the procedure, the indigestible spines could be degraded in the animals' rumens.

\section{CONCLUSION}

After their removal from the field, $P$. gounellei plants can be stored either under a tree or in ventilated storage facilities without losing their nutritional quality. The plants should be stored fresh, and spines should be removed with flamethrowers immediately before using the plants as livestock feed. In addition, these plants can maintain their nutritional quality over a 31 day storage period. A greater amount of $P$. gounellei plants can be harvested regardless of their immediate use, leading to decreased costs for cutting and transportation.

\section{REFERENCES}

BARBOSA, H.P. Tabela de composição de alimentos do estado da Paraíba - Setor agropecuário. João Pessoa: UTPB/FAPEP, 1997. p.165-168.

CAMPOS, F.P.; NUSSIO, C.M.B.; NUSSIO, L.G. Métodos de análise de alimentos. Piracicaba: FEALQ, 2004. 135p.

CAVALCANTI, C.V.A.; FERREIRA, M.A.; CARVALHO, M.C. et al. Spineless cactus plus urea in replacement of tifton 85 hay in Holstein lactating dairy cows diet. Rev. Bras. Zootec., v.37, p.689-693, 2008.

CAVALCANTI, N.B.; RESENDE, G.M. Consumo de P. gounellei (Pilocereus gounellei (A. Weber ex K. Schum.) Bly. ex Rowl) por caprinos no semi-árido da Bahia. Rev. Caatinga, v.20, p.22-27, 2007.

FONTES, M.M.; DANTAS, J.P.; SILVA, E.E.P. Caracterização química das porções morfológicas do xique-xique (Pilosocereus gounellei). 2010. Available in: $<$ http://aquimbrasil.org/congressos/2010/arquivo s/T22. pdf. Accessed on 20> Accessed in May, 2014.

HALL, M.B. Calculation of non-structural carbohydrate content of feeds that contain nonprotein nitrogen. Feedstuffs, v.69, p.12-14, 1997. 
LIMA, G.F.C. Alternativas de seleção e manejo de volumosos forrageiros para atividade leiteira no Nordeste. In.: SIMPÓSIO O AGRONEGÓCIO DO LEITE NO NORDESTE: alternativas tecnológicas e perspectivas de mercado, 1998, Natal. Anais... Natal: EMPARN/ FIERN/SENAI, 1998. p.192.

MALAININE, M.E.; DUFRESNE, A.; DUPEYRE, D. et al. Structure and morphology of cladodes and spines of Opuntia ficus indica. Cellulose extraction and characterisation. Carbohydr. Polym., v.51, p.77-83, 2003.

NEVES, A.L.A.; PEREIRA, L.G.R.; SANTOS, R.D. et al. Plantio e uso da palma forrageira na alimentação de bovinos leiteiros no semiárido brasileiro. Juiz de Fora: Embrapa, 2010. 7p. (Comunicado Técnico, 62).

NUTRIENT requirements of dairy cattle. Washington: National Academy Press, 2001. $381 \mathrm{p}$.

OFFICIAL methods of analysis. 15.ed. Arlington: AOAC International, 1990.

PEREIRA FILHO, J.M.; SILVA, A.M.A.; CEZAR, M.F. Manejo da Caatinga para produção de caprinos e ovinos. Rev. Bras. Saúde Prod. Anim., v.14, p.77-90, 2013.

PERFIL básico municipal 2011. Tauá: IPECE, 2011. 18p.

SANTOS, M.V.F.; FARIAS, I.; LIRA, M.A. et al. Colheita da palma forrageira (Opuntia ficus indica Mill) cv. gigante sobre o desempenho de vacas em lactação. Rev. Bras. Zootec., v.27, p.33-39, 1998.
SANTOS, M.V.F.; LIRA, M.A.; DUBEUX JUNIOR, J.C.B. et al. Potential of Caatinga forage plants in ruminant feeding. Rev. Bras. Zootec., v.39, p.204-215, 2010.

SANTOS, M.V.F.; LIRA, M.A.; FARIAS, I. et al. Efeito do período de armazenamento póscolheita sobre o teor de matéria seca e composição química das palmas forrageiras. Pesqui. Agropecu. Bras., v.27, p.777-783, 1992.

SILVA, J.G.M.; LIMA, G.F.C.; AGUIAR, E.M.; RÊGO, M.M.T. P. gounellei e Mandacaru na alimentação animal. Natal: EMPARN, 2013.

SILVA, J.G.M.; SILVA, D.S.; FERREIRA, M.A. et al. P. gounellei (Pilosocereus gounellei (A. Weber ex K. Schum.) Bly. ex Rowl.) as substitute for silage sorghum (Sorghum bicolor L. Moench) Fed to Dairy Cows. Rev. Bras. Zootec., v.34, p.1408-1417, 2005.

SILVA, J.G.M.; SILVA, D.S.; PEREIRA, W.E. et al. Características morfológicas e produção do P. gounellei cultivado em diferentes densidades. Rev. Cententauro, v.2, p.8-17, 2011.

SISTEMA brasileiro de classificação de solos. 2.ed. Rio de Janeiro: Embrapa-SPI, 2009. 286p.

SISTEMA brasileiro de classificação de solos. 3.ed. Rio de Janeiro: Embrapa, 2013. 306p.

STATISTICAL analysis system: SAS system for Windows. Version 8.0. Cary: SAS Institute, 2003. (CD-ROM).

VAN SOEST, P.J.; ROBERTSON, J.B.; LEWIS, B.A. Methods for dietary fiber, neutral detergent fiber, and nonstarch polysaccharides in relation to animal nutrition. J. Dairy Sci., v.4, p.35833597, 1991. 